\title{
THE ABIDING LEGACY OF THE REFORMATION'S CONFESSIONAL ORTHODOXY: THE REQUIRED VOWS OF WESTMINSTER SEMINARY PROFESSORS AND NAPARC MINISTERS ${ }^{1}$
}

\author{
Peter A. Lillback \\ Westminster Theological Seminary \\ Correspondence: plillback@wts.edu
}

\begin{abstract}
This article revisits how Christians since almost two millenniums have made use of creeds and confessions. Especially confessional vows used at Westminster Theological Seminary, also refer to the vows of the churches who are members of NAPARC (The North American Presbyterian and Reformed Council). First, it examines the historical overview of various Reformed confessions, and historical survey of Reformed confessions from the Reformation to the present. Then, Westminster seminary's Presbyterian and Reformed heritage, and finally, authority of and subscription to the confessions. To define Reformed confessional theology which arose in the sixteenth and seventeenth century, this article include the table of the confessions of Westminster seminary or the NAPARC churches.
\end{abstract}

KEYWORDS: creeds, confessions, Westminster, Reformed

ABSTRAK: Artikel ini meninjau kembali bagaimana orang Kristen sejak hampir dua milenium memanfaatkan kredo dan pengakuan-pengakuan iman. Sumpah pengakuan khusus yang digunakan di Westminster Theological Seminary, juga merujuk pada sumpah gereja-gereja yang menjadi anggota NAPARC (Presbyterian Amerika Utara dan Dewan Reformasi). Pertama, ia mengkaji ikhtisar sejarah berbagai pengakuan Reformed, dan survei historis pengakuan Reformed dari Reformasi hingga saat ini. Kemudian, warisan Presbyterian dan Reformed seminari Westminster, dan akhirnya, otoritas dan berlangganan pengakuan. Untuk mendefinisikan

\footnotetext{
This paper was presented in part at the University of Zurich in May 2017. I am grateful for the excellent assistance of Dr. Bernard Aubert, managing editor of Unio Cum Christo, in its preparation.
} 
teologi pengakuan Reformed yang muncul pada abad keenam belas dan ketujuh belas, artikel ini termasuk tabel pengakuan seminari Westminster atau gereja-gereja NAPARC.

KATA KUNCI: kredo, pengakuan, Westminster, Reformed

\section{Part I: The History of the Reformed and Presbyterian Confessions}

That system of theology, that body of truth, which we find in the Bible is the Reformed faith, the faith commonly called Calvinistic, which is set forth so gloriously in the Confession and catechisms of the Presbyterian church. It is sometimes referred to as a "man-made creed." But we do not regard it as such. We regard it, in accordance with our ordination pledge as ministers in the Presbyterian church, as the creed which God has taught us in his Word. If it is contrary to the Bible, it is false. But we hold that it is not contrary to the Bible, but in accordance with the Bible, and true. - J. Gresham Machen (1929) ${ }^{2}$

Why care about creeds and confessions of time long past? Indeed, in our age everyone seems entitled to his or her own belief; even in churches where the Bible is valued, the following sentiment often prevails, "No creed but the Bible." This too challenges the use and validity of creeds. In this context, Reformed Christians with orthodox convictions and Westminster Theological Seminary among them reaffirm their heritage and confessions based on Scripture. Theological truths are not relative for those in the historic Reformed tradition.

This paper reflects the emphases of Thy Word Is Still Truth: Essential Writings on the Doctrine of Scripture from the Reformation to Today (eds. Richard B. Gaffin, Jr. and Peter A. Lillback, Presbyterian and Reformed, 2013). There the foundational value of Scripture is reasserted - "the foundation of the apostles and prophets" built upon Christ the rock (Eph. 2:20). There a mine of sources was provided to defend Scripture alone (sola Scriptura) as the only infallible rule of faith and practice. Sola Scriptura, however, does not imply that individual Christians expound Scripture by themselves or that each Protestant is a pope with a Bible in the hand. In order to defend the faith, unify the church, guard against false doctrines, etc., the Reformed churches since almost five centuries and Christians since almost two millenniums have made use of Confessions and creeds. This tome wants to highlight the texts of ancient creeds, confessions that still serve as secondary standards in many Reformed denominations, and other Reformed confessions of significance for our tradition.

2 J. Gresham Machen, "Westminster Theological Seminary: Its Purpose and Plan," in D. G. Hart, ed., Selected Shorter Writings: J. Gresham Machen (Phillipsburg, N.J.: P\&R Publishing, 2005), 191. 
Confession of Faith or Gallican Confession was composed at the first French Synod in Paris (1559) partly to address the precarious situation of the French Reformed under persecution and partly to offer a unified confession. Antoine de Chandieu (ca. 1534-91), a French pastor and theologian, was probably the main contributor to the confession. It was only officially adopted at the Synod of La Rochelle in 1571 and is thus sometimes known as the Confession of La Rochelle. It is partly based on a draft provided by Calvin shortly before the Paris Synod and, as we will see, it influenced several other Reformed confessions. Theodore Beza (1519-1605), Calvin's collaborator and successor in Geneva, wrote [Beza's] Confession of Faith in 1558 as a personal testimony to his Catholic father about the Reformed faith; the French edition was published in 1559 and an expanded Latin edition with a wider audience in view was published in 1560. Beza's confession can be understood as an expansion of the Geneva Catechism and a summary of Calvin's Institutes. Besides influencing contemporary Reformed theologians and confessions, Beza's confession was adopted in a revised form as the confession of the Reformed churches in Hungary and Romania.

National Reformed confessions were drafted throughout Europe. With the last two confessions, we observed a movement from Geneva to other countries where the Reformation took roots. The next four confessions offer other examples of national confessions bearing witness to the expression of the Reformed faith in various geographical contexts. The Scottish Confession of Faith was written in 1560 by John Knox (ca. 1514-72) and other Scottish theologians for the Scottish parliament. The confession was adopted shortly thereafter. This confession remained in place until the Scots adopted the Westminster Confession in 1647. The Belgic Confession of Faith was written in 1561, originally in French, mainly by Guido de Brès (ca. 1522-67) to defend the Reformed faith in the Low Countries in light of catholic persecution as the French had done two years earlier. The confession consciously draws on its French counterpart and its structure, but the Belgic Confession shows also affinities with Beza's confession. The confession was revised at the Synod of Dort and is part along with the Heidelberg Catechism and the Canons of Dort of the Three Forms of Unity. The Heidelberg Catechism was commissioned by Elector Frederick III for the purpose of instruction of the youth and religious unity in his city. It was written by a committee of theologians headed by Zacharius Ursinus (1534-83) and Caspar Olevianus (1536-87) in 1563. It is pastoral in character and deals with the themes of misery, redemption, and gratitude. Written within the context of the Augsburg Confession, it clearly reflects Reformed tendencies. It is one of the most beloved Reformed catechism and it overtook the Geneva Catechism in importance. The Second 
Helvetic Confession (1566) was written by Bullinger as a personal confession in time of sickness. It is the culmination of several confessional efforts in Switzerland in particular the Consensus Tigurinus. The Second Helvetic Confession, though longer in size, is a very pastoral summary of Reformed theology. This confession is one of the most influential Reformed confessions and it was adopted by the Reformed church in Poland.

The Canons of Dort and the Westminster Standards both provide mature statements of Reformed theology. Though the Canons of Dort (1618-1619) were written to exclude the rationalistic Arminian theology of the time, they offer a balanced definition of election and related topics. For instance, mission and the free offer of the gospel are strongly affirmed. In response to the then-current Arminian threat, an international synod was gathered at Dort. The Canons that resulted from this meeting should not be viewed as a comprehensive statement of Reformed theology, rather the Canons' focus on the five points of Calvinism taught in them comes as a direct response to the five articles of the Remonstrants. The Canons also served the purpose of unifying the Reformed and prepared the way for the Westminster Assembly. A few decades later, the Westminster Assembly gathered to provide a unified view of doctrine and church government for Britain. The texts produced by the Westminster divines touched upon both doctrinal and pastoral issues. For instance, the Westminster Confession (1647) provides a full exposition of the Reformed faith without omitting some pastoral emphases. The Shorter Catechism (1647) was written to instruct the children in the same system of doctrine and the Larger Catechism (1648) was meant for those who wanted to go deeper and teach others. These Standards have enduring influence on Presbyterian Churches throughout the world and a central role at Westminster Theological Seminary.

In recent decades, Westminster Theological Seminary has in addition issued clarifications or doctrinal statements on specific topics. These clarifications are not confessions per se, but theological statements that clarify issues that arose during the Seminary's history in light of her secondary standards, the Westminster Standards. First, within the Faculty there arose in the 1970s a debate concerning justification and its relationship to sanctification. After sharp debates, the issue was dealt with and the "Westminster Statement on Justification" (1980) was composed to clarify the Seminary's position. Second, in the nineties in particular, debates about views on creation occupied conservative Presbyterians. Both the PCA (Presbyterian Church in America) and OPC (Orthodox Presbyterian Church) set up special committees to study these issues and offered their own recommendations. Westminster's statement, "Westminster Theological Seminary and the Days 
of Creation" (1999) has a more modest goal: it seeks to answer the question as to whether subscription to the Westminster Standards requires a 24 hour view of the days of creation (cf. WCF 4.1). Third, the last issue is of more foundational significance and relates to the implication of the doctrine of Scripture as found in the first chapter of the Westminster Confession. At the beginning of this new millennium, this concern grew as a former professor published views on inspiration challenging its traditional definition. The "Affirmations and Denials Regarding Scripture" or "Affirmations and Denials Regarding Scripture" (2008) tackles anew the Seminary's position on inspiration and its relationship to the disciplines of biblical studies. These three documents are not meant to supersede the Westminster Standards, but rather clarify certain points in the face of contemporary challenges.

\section{Historical Survey of Reformed Confessions from the Reformation} to the Present

Next, we look at the broader picture at various collections of confessions from the time of the Reformation to the present. ${ }^{3}$ From its inception to the present, Protestant confessions aim at reforming the Roman Catholic Church and are thus written in reaction to her. The earliest Lutheran and Reformed texts were written for disputation with Catholics and aimed chiefly at the abuses in the church. Among them are Luther's Ninety-five Theses (1517), Zwingli's Sixty-seven Articles (1523), and the Ten Theses of Berne (1528). A significant move forward in the development of confessional texts occurred around the Diet of Augsburg (1530). Though only the Lutheran side was allowed to presents its confession in the Confession of Augsburg, there were other "Augsburg Confessions" written at the time. The Roman Catholic offered a rebuttal in their Confutation, the Tetrapolitan Confession written by Martin Bucer on behalf of four Reformed city represented early Reformed theology, and Zwingli's Ratio Fidei advocated the position of Zurich. In these documents we begin to see a systematization of the views of the various traditions, but still in light of the debates between the Protestants and the Catholics. The meeting of the Council of Trent (1545-63) and its production of confessional statements and catechism was certainly an important factor in the development of Reformed confessions. This interaction with Catholic is discernable in most Reformed confessions up to the documents produced by the Westminster Assembly.

\footnotetext{
3 To understand the Reformed creedal tradition in contrast to the Lutheran and Catholic traditions at the key juncture of the second half of the Sixteenth century, the following work is especially helpful, Raitt, ed. Shapers of Religious Traditions.
} 
In the early days of Reformed theology, especially in Switzerland, the Reformers through their confessions defined themselves in contrast to the Anabaptist movement. Both Zwingli and Calvin wrote responses to the Schleitheim Confession (1527). The Magisterial Reformers needed to show that by their reforms of the church, they did not intend to overthrow the government and civil authorities. This was also crucial in the French context and this apologetic aspect is visible in the French Confession of Faith. Back in Zurich, these early debates over baptism helped the development of covenant theology with the assistance of Zwingli and Bullinger.

While Calvin and Bullinger are dominant players in the production of Reformed confessions, the Reformed tradition displays a certain geographical and theological variety in its confessional witness. Calvin did indeed write the Geneva Catechism and had a hand in the French Confession of Faith and Bullinger was involved in the First Helvetic Confession (1536) and composed the Second. Moreover, both Calvin and Bullinger were involved in the Consensus Tigurinus. At the same time, however, towards the end of the Council of Trent and after, we observe a blossoming of a variety of Reformed confessions throughout Europe. The Reformed and their confessions emphasized the authority of Scripture and its application to local contexts; in contrast, the Lutherans gave more weight to the authority of the confessions which were more centralized.

This brings us to the Lutheran challenge and the development of the Harmony of Confessions. Within Lutheranism, under the leadership of Melanchthon, one group (the Philipists) developed a view of the Lord's Supper closer to that of Calvin. Melanchthon's revision of the Augsburg Confession (the Variata of 1540) opened the door for the Reformed to potentially live under its protection. After Luther's death, however, hope of reconciliation between Lutheran and Reformed dwindled. In this context and under Calvin's leadership, the Consensus Tigurinus aimed at least to secure unity among the Reformed. Similarly, the Heidelberg Catechism can be perceived as an effort to formulate Reformed theology in a Lutheran context. Instead of bringing the Reformed and Lutheran closer together, these efforts had the effect of strengthening the Lutheran identity. In other words, the anti-Reformed party within Lutheranism gained ground. This opposition culminated in the Formula of Concord (1577) a collection of official Lutheran catechisms and confessions that defined Lutheran orthodoxy reminiscent of the way the Council of Trent defined Catholicism. The result was the clear exclusion of the Reformed perspective. In response to this challenge, Reformed theologians developed the first collection of confessions. 
Under the leadership of Theodore Beza, a Harmony of Confessions of Faith was published in 1581. The articles of the different confessions were presented side by side under theological topics. The Harmony contained a variety of confessions (both Lutheran and Reformed) and were organized around the outline of the Second Helvetic Confession. This collection was well received in France, Switzerland, and England. It received a second life with the publication of an English version by Peter Hall in 1848 with additional Reformed confessions.

From the Synod of Emden (1571) to the Synod of Dort (1618-19), we observe the slow development of what would be known as the Three Forms of Unity. The Synod of Emden marks the official birth of the Dutch church in similar way as the Synod of Paris (1559) constituted the starting point of the French Reformed church. The Synod of Emden met shortly after the Synod of La Rochelle where the French Confession of Faith was officially adopted. The Synod of Emden included both French and Dutch speaking representative and met in Emden, Germany, because of persecutions. For our purposes, two elements are noteworthy. To preserve the unity the brothers subscribed to the Belgic Confession and as a show of solidarity for the French churches they also adopted the French Confession (article 2). Furthermore, for the instruction of the youth, they recommended the Geneva Catechism for the French speaking churches and the Heidelberg Catechism for the Dutch speaking congregations (article 4). We observe both the recognition of the first two legs of the Three Forms of Unity (the third not yet being written) and that the French Confession was acknowledged and the Geneva Catechism was not yet eclipsed by its counterpart from Heidelberg.

This unity of faith would be challenged by the rise of the rationalism of the Arminian position in Holland and of the beginning of Socinianism. The preaching and teaching of Jacob Arminius (1560-1609) and The Five Arminian Articles (1610) posed a serious challenge to the confession of the Dutch church. This teaching framed and gave rise to the debate of the Synod of Dort. Dort was an international gathering of Reformed theologians and the Canons of Dort resulting from this synod represent a nuanced response to the threat of Arminianism. Not only were the Canons composed there, but also the Belgic Confession was revised by the delegates; further the Heidelberg Catechism was reaffirmed. We thus see the constitution of the Three Forms of Unity, so essential for many Reformed denominations up to today.

While the Canons of Dort were and are adopted by these churches who adhere to the Three Forms of Unity, other church bodies welcomed it as well. Members of the Church of England and not stricter Puritans were delegates at Dort; therefore the Canons of Dort were well received shortly 
Here I consider the confessional vows used at Westminster Theological Seminary. Confessionalism at Westminster Theological Seminary includes vows that the trustees and faculty are required to take. Here also, we will refer to the vows of the churches who are members of NAPARC (The North American Presbyterian and Reformed Council). It is my hope that this essay would be of assistance to both scholars and for the building up of Christians and churches and thereby spread the knowledge of the gospel and Scripture conveyed by these confessions.

\section{Historical Overview of Various Reformed Confessions}

The Three Ecumenical Creeds present the common theological heritage of the church. These creeds were commonly accepted at the time of the Reformation and are still in use in churches today. They define orthodox Trinitarian theology and Christology from a Western perspective. The Apostles' Creed though not written by the apostles is a compact summary of the apostolic teaching. Its roots can be traced back to the second century. It is more a Western creed. The Nicene Creed or Nicaeno-Constantinople Creed, apart from the filioque clause ["and the Son" added to express the double procession of the Holy Spirit], expresses the classical formulation of the Eastern Church against the background of heretical teachings. It is therefore the most ecumenical creed of the three. The Athanasian Creed or Quicumque (its first word in Latin) is named after Athanasius (A.D. 298-373) though it is a Western Creed arising from the fifth or sixth centuries. It is divided into two parts, one on the Trinity and the other on Christology, and its perspective reflects the contribution of Augustine (A.D. 354-430). In addition, the Definition of Chalcedon (A.D. 451) is also an important Christological definition from the East building on and enshrining the decisions of earlier councils.

Four Reformed confessions are linked to the reformation effort of John Calvin (1509-1564). The 1541 Geneva Catechism was written by Calvin upon his return to Geneva from Strasbourg for the purpose of strengthening the Reformation there through catechetical instruction. Thanks to its 1545 translation, it received more international exposure. This text is an important early formulation of Reformed theology and is a fine doorway to Calvin's Institutes. Calvin together with Heinrich Bulllinger (1504-75) Zwingli's successor in Zurich - worked on the Consensus Tigurinus or Zurich Agreement in 1549 on the Lord's Supper, which was published in 1551. This agreement of twenty-six articles represents a compromise between Calvin's view of the spiritual presence and Zwingli's memorial view and would become essential for the unity of the Reformed in Switzerland. The French 
after in England. While the French were not allowed by the king to send their delegates to the Synod; their own French synod wholeheartedly welcomed and subscribed to the Canons of Dort. In Switzerland the Canons of Dort were also welcomed. The Swiss in addition wrote the Helvetic Consensus Formula (1675) at the end of the confessional age. Though the official status of this confession would not last, it was designed to guard the church against the theology of Saumur (a modification of Calvinism) and attacks against the teaching of the Synod of Dort. We see therefore that the Canons of Dort whether in conjunction with the Belgic Confession and Heidelberg Catechism or in connection with other Reformed confessions had a wide international appeal.

The Westminster Assembly (1643-49) gave rise to another collection of Confessional documents, but this time all of them were composed at the assembly in one place and time. The Assembly was called by the parliament at the time of the civil war for the purpose of establishing a more unified Reformed church in government and doctrine in Britain. In the immediate horizon, the Westminster divines were dealing with the reformation of the Church of England, but other concerns occupied them as well such as Roman Catholicism, Arminianism, and the recent rise of the Quakers. At first, the delegates were asked to revise the Thirty-nine Articles (1563) - the main confession of the English Reformation; but then it was decided that they would write a new confession, the Westminster Confession. This confession was not of course new, but draws in particular from the Irish Articles of Religion (1615) by James Ussher and reflects in a mature and balanced way upon the various debates since the beginning of the Reformation. The assembly also composed two catechisms (the Shorter and the Larger Catechisms) and other documents including the Directory for the Public Worship of God. Though not as international as the Synod of Dort-indeed, the Westminster Assembly had delegates mainly from Britain and advisors from Scotland, it still represent mature international Calvinism. Paradoxically, the impact of the Westminster Standards was minimal and short-lived in England; in Scotland, however, the Standards even replaced the Scots confession and historic orthodox Presbyterians throughout the world and in the United States in particular still hold to the Westminster Standards as the confession of their faith.

In America, Presbyterian churches have adopted the Westminster Standards. The official acknowledgments of these standards can be dated to the Adopting Act of the 1729 Philadelphia Synod. A few words about this Act are in order as it impacted subsequent and current debates about subscription to the standards among American Presbyterians. The Act is 
somewhat of a compromise between a strict and a loose view of subscription. First, it allows for the officers of the church to express scruples or exceptions that are examined by the official church body. Thus, by allowing such objections, the synod acknowledged that the confession and catechisms are not inspired, but secondary standards under the ultimate authority of Scripture. Back then, however, the exceptions were of a very limited nature, mainly pertaining to the article on the Magistrate. Second, the Act contains two different statements: one from the morning which appears to be less strict (relating to essential doctrines) and one from the afternoon proposing a stricter view. While both texts ought to be considered, it is legitimate to argue that the later and final text represents the more authoritative part of the synod. Third, most Presbyterian churches have procedures in place to allow for the revision of the Confession and catechisms. In the American context, the Confession was revised to reflect the shift from the magisterial reformation to recognition of the religious pluralistic American context. Note though that if the option of revising the confession is open and reflects its subordinate role in relation to Scripture, the process of revision is usually difficult in order to avoid a rash change to the secondary standards. Below, we address the issue of subscription in general and at Westminster Seminary. The Seminary's view accords with the direction set by the Adopting Act.

The original Princeton theological tradition continued by Westminster Seminary emphasized the Westminster Standards with their covenant theology, as well as the Consensus Tigurinius, the Helvetic Consensus Formula, and the Canons of Dort. However, the modern age, from the nineteenth century to the present, has given rise to various modern collections of confessions and creeds. In order to better evaluate them we can classify them into three distinct categories: historical/ecumenical, Reformed/neo-orthodox, and historic/Reformed.

First, the historical/ecumenical collections view the confessions in their historical contexts and include confessions from various Christian traditions. The classic example of this is the three volume collection by Schaff which includes representative Christian traditions from all confessions from the earliest time of the church to the nineteenth century. On a much smaller scale, Mark Noll's book includes shorter confessions representing the various confessional trends at the time of the Reformation.

Second, Reformed/neo-orthodox collections reflect the rediscovery of the confessions under the impetus of Karl Barth. These often give precedence to sixteenth century confessions over against so-called more scholastic confessions. They also add twentieth century shorter confessions starting with the Barmen Declaration (1534). This reflects the heritage of the confessing 
church during the darker days of absolutism in Germany. The collection by Arthur C. Cochrane is a classic example of this orientation. The Book of Confessions of the PCUSA (Presbyterian Church in the United States) can also be viewed in this light: though it retains for historical reasons the Westminster Standards, it includes confessions more congenial to neo-orthodoxy, such as the Barmen Declaration with other modern Confessions such as the Confession of 1967. This latter confession qualifies the classic Reformed confessions for modern Christians.

Third, the historic/Reformed type of collections seeks to convey the historic Reformed confessions of the sixteenth and seventeenth centuries. Arising from a closer adherence to the theology of Reformation and post-Reformation theology, these collections tend to limit themselves to the confessional age of the Reformation, but do not shy away from later expressions of Calvinism such as the Canons of Dort and the Westminster Standards. While the second type conceives of confessions as evolving and needing readjustment to the present, this third type appreciates more the Reformed confessions as abiding truth as their theology seeks to be based on the Biblical truths that the Reformation recovered. An example here is the multivolume work by James Dennison that provides English translations of most Reformed confessions of the sixteenth and seventeenth centuries. Along similar lines, in Reformed Confessions Harmonized, Joel R. Beeke and Sinclair B. Ferguson present the Three Forms of Unity, the Second Helvetic Confession, and the Westminster Standards in parallel.

Both the OPC and PCA have editions of the Westminster Standards that constitute the confessional standards of their churches. The OPC edition has in addition carefully chosen and sifted biblical texts to support the doctrines of the confession. Similarly, the Christian Reformed Church published her confessional standards with Scripture references in one volume, Ecumenical Creeds and Reformed Confessions (which include the three classic creeds and the Three Forms of Unity). The French collection under the direction of Professor Olivier Fatio of Geneva reflects a more French/Swiss selection. After the three creeds, it includes the Geneva Catechism and the French Confession of Faith (more typical of French Reformed); than the Heidelberg Catechism and the Second Helvetic Confession, with their more universal appeal are presented; finally, the Canons of Dort are given (remember that they were approved by both the French and the Swiss).

\section{Westminster Seminary's Presbyterian and Reformed Heritage}

Among the many Reformed confessions, two groups of three stand out, like the two foci of an ellipsis. The one group is the Westminster Standards 
which include the Westminster Confession, the Larger Catechism, and the Shorter Catechism; the other is the Three Forms of Unity composed of the, Belgic Confession, the Heidelberg Catechism, and the Canons of Dort. As we have seen these two collections are linked to the two great international Calvinist gatherings of the seventeenth century.

This twofold emphasis is present in various ways in traditions close to Westminster Theological Seminary. First, Old Princeton Seminary from which Westminster emerged as a Presbyterian institution was rooted in the Westminster Standards. At the same time, Westminster has had connections with Dutch Reformed theology. Through Abraham Kuyper and Herman Bavinck and other Reformed theologians, it was also in touch with Reformed Christians influenced by the Three Forms of Unity. ${ }^{4}$

Second, most of the churches in NAPARC either subscribe to the Westminster Standards or to the Three Forms of Unity or a combination of both (see the chart below). Other Reformed or Presbyterian denominations outside this association gravitate toward one pole or the other. The name of the American publisher Presbyterian and Reformed suggests ties to both traditions as well.

Third, the history and practice of Westminster Theological Seminary reflects this double-emphasis. It should be noted that the official documents to which the trustees and faculty subscribe are the Westminster Standards. This reflects not only the close association of Westminster with Presbyterian denominations in the United States, but also the significant input of Scottish professors such as John Murray and Sinclair B. Ferguson. While the Three Forms of Unity are not officially accepted, they are widely respected. Also, for a long part of its history, several key Westminster professors were associated with the Christian Reformed Church, notably Cornelius Van Til and R. B. Kuiper.

So to summarize, confessions and creeds valued by Reformed Christians can be classified into three categories: the ancient creeds, the Protestant confessions, and the specifically Reformed confessions and catechisms. ${ }^{5}$ The discussion here, however, does not consider Lutheran confessions (such as the Augsburg Confession), even though Reformed Christians agree with

\footnotetext{
4 Even before that, Princeton Seminary had interest in the broader Reformed Confessional tradition. Samuel Miller, for instance, wrote an introduction to the Canons of Dort; see The Articles of Dort, trans. Thomas Scott, with an Introductory Essay by the Rev. Samuel Miller (Philadelphia: Presbyterian Board of Publication, 1856). Another instance is the inclusion of the "The Consensus Tigurinus (1549)" and "The Helvetic Consensus Formula (1675)" in Archibald Alexandr Hodge's Outlines of Theology (1840).

5 For these divisions, see for instance Pierre Courthial, "En Vue du dialogue entre Protestants et Catholiques romains," in Fondements pour l'avenir (Aix-en-Provence: Kerygma, 1981), 182.
} 
much in these and are indebted to the Lutheran tradition. ${ }^{6}$ Similarly, we do not engage the Thirty-nine articles or 1689 Baptist Confession of Faith, though both of them reflect a Calvinistic theological outlook.

The study of the Reformed tradition reveals that it is not monolithic and only centered upon the theology of John Calvin. There is diversity within the Reformed traditions. Thus the confessional writings most closely associated with Calvin (the Geneva Catechism and the French Confession of Faith) have been overshadowed by others such as the Heidelberg Catechism and the Westminster Confession of Faith. From a Reformed perspective, we can speak of a Reformation age lasting from the sixteenth century to the middle of the seventeenth century (see for instance B. B. Warfield and J. Gresham Machen's perspective on the confession below). This time corresponds to the period between the rediscovery of the gospel at the Reformation and the erosion of the biblical orthodoxy under the pressure of the Enlightenment. In this development the Westminster Standards constitutes a climax - partly because refinements of individual doctrines occurred afterwards.

While we share an appreciation for Reformed confessions with Barthian or neo-orthodox theologians, we differ at key junctures with them. Followers of Karl Barth often show a preference for earlier confessions as less scholastic over against later ones such as the Canons of Dort or the Westminster Standards. Barth himself commented on the Heidelberg Catechism and the Scots Confession. Thomas Torrance in the introduction to his collection of catechism is somewhat critical of the theology of the Westminster Standards. Second, Barthian collections include confessions from the Twentieth century. For instance, the Barmen declaration is included in the collections by Wilhelm Niesel and Cochrane. The 1967 Confession is included as well in the Constitution of the PCUSA church. These inclusions reflect a more fluid conception of doctrine in contrast to the traditional Reformed perspective where doctrines are based on Scripture and are more defined.

At this point, it might be well to consider some objections to the presence of confessional references or prooftexts. A common view, is that a prooftext approach to theology is antiquated and does not do justice to a more organic and comprehensive understanding of Scripture and theology. ${ }^{7}$

\footnotetext{
6 For John Calvin's attitude toward the Augsburg Confession and rejection of the same, see Peter A. Lillback, "Calvin's Final Verdict on the Augsburg Confession," in Aspects of Reforming: Theology and Practice in Sixteenth Century Europe (ed. Michael Parsons; Studies in Christian History and Thought. Milton Keynes, Bucks: Paternoster, 2013), 96-117. Though the Augsburg Confession is not seen here as a typically Reformed documents, it has often been valued by Reformed Christians and has a great historical significance in the history of the Reformation.

7 See the discussion of G. C. Berkouwer in his Holy Scripture, trans. and ed. Jack B. Rogers, Studies in Dogmatics (Grand Rapids, Mich.: Eerdmans, 1975), 279-84; and that of Kevin J. Vanhoozer in his The Drama of Doctrine: A Canonical Linguistic Approach to Christian Theology (Louisville, Ky.: Westminster John
} 
It is true that there is a danger of marshaling series of Scripture references to prove doctrines in a way that does not do justice to an understanding of individual passages of Scripture in context. However, a careful consideration of the Scripture references adduced in the confessions I believe reveals that this critique generally does not apply to the Reformed confessions and their use Scripture proofs.

\section{Authority of and Subscription to the Confessions}

It is appropriate to start by acknowledging that confessing the faith was at the heart of the sixteenth-century Reformation. If the Reformation rediscovered the doctrine of justification by faith and formulated anew biblical doctrines, the concern of the Reformers was not merely to refine systematic theology or the private individual faith of individuals, but rather the public corporate proclamation of this rediscovered faith upon which salvation was closely tied. This central reality was not invented out of thin air, but has deep roots in the Bible itself. The New Testament passages cited on the title page of the Belgic Confession illustrate this point well. Some passages from the synoptic gospels promise acceptance from the Father for those who confess Christ in the midst of opposition (Matt. 10:32-33; Mark 8:38; Luke 9:26; cf. also 2 Tim. 2:12). Romans 10:10 asserts, "For with the heart one believes and is justified, and with the mouth one confesses and is saved" (ESv); thus, public confession is essential to salvation. First Peter 3:15 is also brought forth here as it was in the French Confession of Faith; this highlights the apologetic character of the confessions. To these passages we could add the witness of John in John 12:42, "Nevertheless, many even of the authorities believed in him, but for fear of the Pharisees they did not confess it, so that they would not be put out of the synagogue" (ESv). These passages show the confessional nature of biblical Christianity; let us now turn to the question of subscription to a confession.

Confessions are subordinate standards, but are standards nevertheless. Indeed, Scripture is "the only rule of faith and obedience" (WLC 3; cf. WSC 2; WCF 1.2). This implies that no documents produced by the church can compete with the authority Scripture. A distinction is helpful to further our understanding of the questions. Theologians have discerned two different

Knox Press, 2005), 270-72. For his part, John M. Frame offers a short explanation and defense of the use of proof-texts; see his The Doctrine of the Knowledge of God, A Theology of Lordship (Phillipsburg, N.J.: Presbyterian and Reformed, 1987), 197. Richard A. Muller offers a brief historical analysis of proof-texting in relation to the Westminster Confession; see Richard A. Muller, "Part 1: Scripture and the Westminster Confession," in Richard A. Muller and Rowland S. Ward, Scripture and Worship: Biblical Interpretation and the Directory for Worship (Philipsburg, N.J.: P\&R Publishing, 2007), 69-72. 
motivations behind the subscription to a confession: a quia-subscription ("because") and a quatenus-subscription ("insofar as"). ${ }^{8}$ Some Lutheran subscribe to the confessions "because" they are Scripture, that is they represent faithfully biblical teaching; a looser subscription understanding to subscription argues that we subscribe to confessions "insofar as" they are Scripture, that is insofar as they convey the biblical message. The quatenus-subscription seems preferable because it better distinguishes between Scripture as the ultimate standard and the confessions as secondary standards. A quatenus-subscription, however, should not be construed as a relativizing of the authority of the confession according to the whim of each individual. Another classic distinction provides additional clarification to the discussion. It is customary to speak of the Bible as the norma normans ("norming norm") and the confession as the norma normata ("normed norm"). In other words, the Bible is the rule that shapes or rules all our thoughts and actions and the confession is a rule that is shaped by Scripture, the ultimate rule. Confessions were and are drafted by churches to faithfully represent the teaching of Scripture to serve various purposes; this is why individuals and churches subscribe to them.

Before addressing some of the specifics of subscription in the context of Presbyterian history and Westminster, a consideration of the Barthian outlook on subscription will help to clarify the classic Reformed view. The Reformed theologian Klaas Runia helpfully summarizes the issues in his 1959 article "The Authority of the Confession: The Barthian and the Reformed View." ${ }^{\prime 9}$ Runia distinguishes three attitudes towards the confessions: "doctrinal liberty" (the liberal view), the confession as "strictly binding" (the Reformed view), and the Barthian view in between (pp. 6-7). For Barth the confessions are limited by their historical contexts (p. 9), yet they have still a role to play in the church. For him, the statements of the confessions are not binding, but the confessions give "direction" to our theology (p. 11). Barth's well known reservation towards the definition of Chalcedon can illustrate the point of accepting a creed as directional, yet not necessarily authoritative in its statements. While Runia welcomes Barth's positive outlook on the Reformed confessions (p. 13), he considers Barth's view of subscription as too weak. ${ }^{10}$ Runia helpfully suggests that holding to

\footnotetext{
8 For more detail about this distinction at the time of the Reformation and its implication for the church today, see Peter A. Lillback, "Confessional Subscription Among the Sixteenth Century Reformers," in The Practice of Confessional Subscription (Lanham, Md.: University Press of America, 1995), 33-66.

9 In this paragraph we follow the analysis found in Klaas Runia, "The Authority of the Confession: The Barthian and the Reformed View," The Reformed Theological Review 18, 1 (February 1959), 6-20. His book Reformation Today (London: Banner of Truth, 1968) is also relevant for the topic of confessions.

10 One could explore Barth's views on the confessions in relation to his view of Scripture; one could
} 
both a quia-subscription and a quatenus-subscription enables one to avoid subjectivism and "a confessionalistic absolutism" respectively.

If Barthianism presents itself as a middle road between doctrinal relativism and strict confessionalism; Westminster Seminary's view on subscription, in line with Presbyterian history, offers a more confessional middle road. We have already seen that in the Adopting Act (1729), the Westminster Standards were accepted as the standards for American Presbyterianism, yet room was made for some scruples thus recognizing the distinction between Scripture and those secondary standards. In many ways, Westminster Seminary strives to carry on the legacy of Old Princeton Seminary. ${ }^{11}$ Old Princeton led the way in promoting a confessional Christianity within the Presbyterian church of the time. ${ }^{12}$ It is lesser known, however, that the Princetonians had a nuanced view of confessions. For instance, Charles Hodge, the leading systematician of the Princeton School, advocates a subscription to the "system of doctrine" found in the Westminster Standards. For Hodge, subscription to the Westminster Confession does not mean subscribing to every word of the confession, but to all the main doctrines expressed in it. In other words, for him, there could be some acceptable differences of formulations among Reformed theologians in the Presbyterian Church. ${ }^{13}$ B. B. Warfield's involvement over the debate whether the Westminster Confession should be revised illustrates further this middle road. He made the case that because in the Presbyterian churches America, in contrast to Presbyterian churches in other countries, no subscription to the very words of the confession is required, no revision of the confession is needed. ${ }^{14}$ Princeton's view of subscription should not be viewed as loose, and it contrasts for instance with today's main line Presbyterian churches where subscription to the confessions means

argue that Barth's understanding of Scripture and of language prevents him from fully embracing the Reformed teaching embodied in the Reformed confessions.

11 The writings of William Barker on the Westminster Confession and subscription, though of course not official statements of Westminster Seminary, illustrates continuity with Princeton's view of confessions; see the collection of his articles, Word to the World: The Collected Writings of William S. Barker (Fearn, Ross-shire: Mentor, 2005).

12 Samuel Miller, one of the founders of the school, was very influential in that respect. He wrote important and helpful texts on the subject; see his Doctrinal Integrity: On the Utility and Importance of Creeds and Confessions and Adherence to Our Doctrinal Standards (Dallas, Texas: Presbyterian Heritage Publications, 1989); repr. of The Utility and Importance of Creeds and Confessions (1839) and Letter VI-VIII of Letters to Presbyterians on the Present Crisis in the Presbyterian Church in the United States (1833). For Miller as a "Confessional Churchman," see James M. Garretson, An Able and Faithful Ministry: Samuel Miller and the Pastoral Office (Grand Rapids, Mich.: Reformation Heritage Books, 2014), 110-30.

13 See Charles Hodge, "What Is Meant by Adopting the Westminster Confession?" in A. A. Hodge, The Confession of Faith (Carlisle, Pa.: Banner of Truth, 1958), 420-26.

14 See Benjamin B. Warfield, On the Revision of the Confession of Faith (New York: Anson D. F. Randolph \& Company, 1890), esp. 7-17. 
little more than subscribing to the fundamental doctrines or tenets of the Christian faith. ${ }^{15}$

Westminster Seminary seeks to pursue historic Presbyterian legacy in continuity with Old Princeton Seminary and in contrast to mainline Presbyterian denominations. ${ }^{16}$ Westminster Seminary's high respect for the Westminster Standards is seen in the vows required of the Faculty and the Board of Trustees. ${ }^{17} \mathrm{~A}$ few details about the procedures surrounding subscription at Westminster will help clarify what is meant by subscription. ${ }^{18}$ As Westminster is a confessional school, all the Faculty members (tenured and non-tenured) are required to subscribe to the Westminster Standards. This is a voluntary action on the part of those who teach at Westminster and academic freedom is guaranteed within this confessional framework. ${ }^{19}$ In line with Presbyterian practices, if a faculty member has a scruple or exception, that professor should report it to the Board Trustees and to the faculty for evaluation. ${ }^{20}$ They then decide whether such exception is acceptable within the confessional framework of Westminster. In this context, "Affirmations and Denials Regarding Recent Issues" states that "the meaning of any particular teaching in the Standards is determined by the Board, by referring to the historical record of orthodox Reformed tradition" (I.D). ${ }^{21}$ It follows that the allowance for exceptions is not a subjective process without guidelines. To conclude, at Westminster, the Westminster Standards serve a clear doctrinal framework within which academic freedom can be expressed. The Seminary's view of subscription to the Standards is at the same time very serious and allows for some limited exceptions - treading the middle road of historic subscription traced by our forefathers.

15 See for example the ordination vow of the Presbyterian Church in the U.S.A., see Jack Rogers, Reading the Bible and the Confessions, 66-67.

16 At a time of great challenges to Reformed confessions, the Westminster Faculty composed a symposium on the Bible and confession. This work contains important articles by the Seminary's professors back then and a reprint of an address by Machen. John H. Skilton, ed. Scripture and Confession: A Book about Confessions Old and New (Phillipsburg, N.J.: Presbyterian and Reformed, 1973).

17 These vows are reproduced in this volume. Peter A. Lillback's statement in this volume also witness to a high view of the confessions.

18 We are indebted to an e-mail communication on February 24, 2014 from Rev. George Cottenden for some of this information.

19 The matter of subscription in relation to academic freedom and other topic is raised in Westminster's statement, "Affirmations and Denials Regarding Recent Issues," I. Confessional Subscription, reprinted at the end of our collection. Moisés Silva argued that far from being restrictive, a clear confessional direction actually allows for a great diversity of expressions within certain boundaries; see Moisés Silva, "Old Princeton, Westminster, and Inerrancy," in Harvie M. Conn, ed., Inerrancy and Hermeneutic: A Tradition, A Challenge, A Debate (Grand Rapids, Mich.: Baker, 1988), 78; reprinted in TWIST 891.

20 In the current system, the faculty member reports annually these exceptions to the Provost, who passes them along to the board of Trustees.

21 Part of this "historical record of orthodox Reformed tradition" is the other Reformed confessions besides the Westminster Standards included in this volume. Thus, if the Westminster Standards are the only confessional texts subscribed to at Westminster, other Reformed confessions have also their place. 
Our understanding of subscription to confessions can be enriched by a better comprehension of the various purposes and genres of the confessions. Confessional texts serve among other things to define orthodoxy and refute false doctrines, to instruct the church, to unify Christian, to defend the faith, etc. ${ }^{22}$ Depending on the genre and purpose of a confessional text; one will have a different attitude toward it or appropriation of it. Just to give to examples: Beza's confession is a polemical refutation of Roman Catholicism; in this case, one may agree with the theological content without necessarily embrace the form and style of the argument. Or, take for instance the Westminster Larger Catechism, though it is in Presbyterian churches and at Westminster part of the standards of orthodoxy; its pedagogical format has to be taken into account in its appropriation. We can then conclude that although all confessions and catechisms in this volume convey Reformed theology, a consideration of their various genres and purposes is essential for a right reading and appropriation of them.

It is also important to distinguish between confessions of faith and statements on specific matters. The sixteenth and seventeenth centuries were a time when major Reformed doctrines were defined in the light a renewed reading of Scripture. The confessions that followed these rediscoveries have a great weight. Subsequent statements on particular issues in the twentieth and twenty-first centuries do not necessarily show the same advance in doctrine and do not have the same significance. ${ }^{23} \mathrm{Carl} R$. Trueman in asking whether new confessions are needed, similarly makes the helpful distinction between "occasional statements and confessionally binding documents." ${ }^{24}$ For instance, in this collection and within the context of Westminster, whereas the Westminster Confession is a confessionally binding document, the "Affirmations and Denials Regarding Recent Issues" is more like an occasional statement of some weight, but to which the Faculty and board do not have to subscribe.

Finally, there is a variety of Reformed confessions as can be seen from the table below, some of these confessions are standards of Westminster Seminary or the NAPARC churches. ${ }^{25}$ These confessions are important

\footnotetext{
22 See for instance, Paul Woolley, "What Is a Creed For? Some Answers from History," in Skilton, Scripture and Confession, 95-125; Lillback, "Confessional Subscription".

23 J. Gresham Machen makes a good case for the priority of ancient Creeds and classic Reformed confessions; see his "The Creeds and Doctrinal Advance," in Skilton, Scripture and Confession, 149-57. In that, Machen follows the views of Old Princeton Seminary and his mentor B. B. Warfield.

24 See Carl R. Trueman, The Creedal Imperative (Wheaton, Ill.: Crossway, 2012), 191-97, esp. 196.

25 Some Reformed organizations require subscription to at least one of the historic Reformed confessions. For instance, the World Reformed Fellowship request subscription to a least one of the following confessions: the Belgic Confession, the Canons of Dort, the Gallican Confession, the Heidelberg Catechism, the London Confession of 1689, the Savoy Declaration, the Second Helvetic Confession, the Thirty Nine
} 
to define Reformed confessional theology as it arose in the sixteenth and seventeenth century.

\section{Table of Confessions according to Organizations and Churches ${ }^{26}$}

\begin{tabular}{|c|c|c|c|c|c|c|c|c|c|c|}
\hline & $\mathrm{AC}$ & $\mathrm{NC}$ & AthC & $\mathrm{BC}$ & $\mathrm{HC}$ & $C D$ & WCF & WLC & WSC & Others \\
\hline WTS & & & & $\mathrm{x}$ & $x$ & $x$ & $x$ & $x$ & $x$ & $\begin{array}{l}\text { Justification; } \\
\text { WTS and the } \\
\text { Days of Creation; } \\
\text { Affirmations } \\
\text { and Denials }\end{array}$ \\
\hline NAPARC & & & & $X$ & $x$ & $x$ & $X$ & $X$ & $X$ & \\
\hline ARPC & & & & & & & $x$ & $x$ & $x$ & \\
\hline CanRC & $x$ & $x$ & $x$ & $X$ & $x$ & $x$ & & & & \\
\hline ERQ & $\mathrm{x}$ & $x$ & $x$ & & $x$ & $x$ & $x$ & & & $\begin{array}{c}\text { FCF; CONTEMPORARY } \\
\text { TESTIMONY (1983) }\end{array}$ \\
\hline FRCNA & $x$ & $x$ & $x$ & $X$ & $x$ & $x$ & & & & \\
\hline HRC & $x$ & $x$ & $x$ & $X$ & $x$ & $x$ & $X$ & $X$ & $x$ & \\
\hline KAPC & & & & & & & $X$ & $X$ & $X$ & \\
\hline OPC & & & & & & & $X$ & $X$ & $X$ & \\
\hline PCA & & & & & & & $x$ & $X$ & $x$ & \\
\hline PresRC & & & & & & & $x$ & $x$ & $x$ & \\
\hline RCUS & $x$ & $x$ & $x$ & $X$ & $x$ & $x$ & & & & \\
\hline RPCNA & & & & & & & $x$ & $x$ & $x$ & $\begin{array}{l}\text { Testimony of } \\
\text { the RPCNA }\end{array}$ \\
\hline URCNA & $x$ & $x$ & $x$ & $X$ & $x$ & $x$ & & & & \\
\hline
\end{tabular}

WTS Westminster Theological Seminary, Philadelphia

www.wts.edu

NAPARC The North American Presbyterian and Reformed Council www.naparc.org

ARPC The Associate Reformed Prebyterian Church www.arpchurch.org

CanRC The Canadian (\& American) Reformed Churches www.canrc.org

ERQ Église réformée du Québec [The Reformed Church of

Articles, and the Westminster Confession of Faith; see www.wrfnet.org/about/join (accessed: 06/04/2014). Our collection includes all but the Thirty-nine Articles (Anglican) and the two confessions derived from the Westminster Confession, i.e., the London Confession of 1689 (Baptist) and the Savoy Declaration (Congregationalist). Our collection can thus be of use to such international Reformed organizations.

26 The upper case xs indicate that the confessions are subscribed to by the institution or church. The lower case xs indicate, in contrast, that the confessions are valued, but are not accepted as official/authoritative documents. 


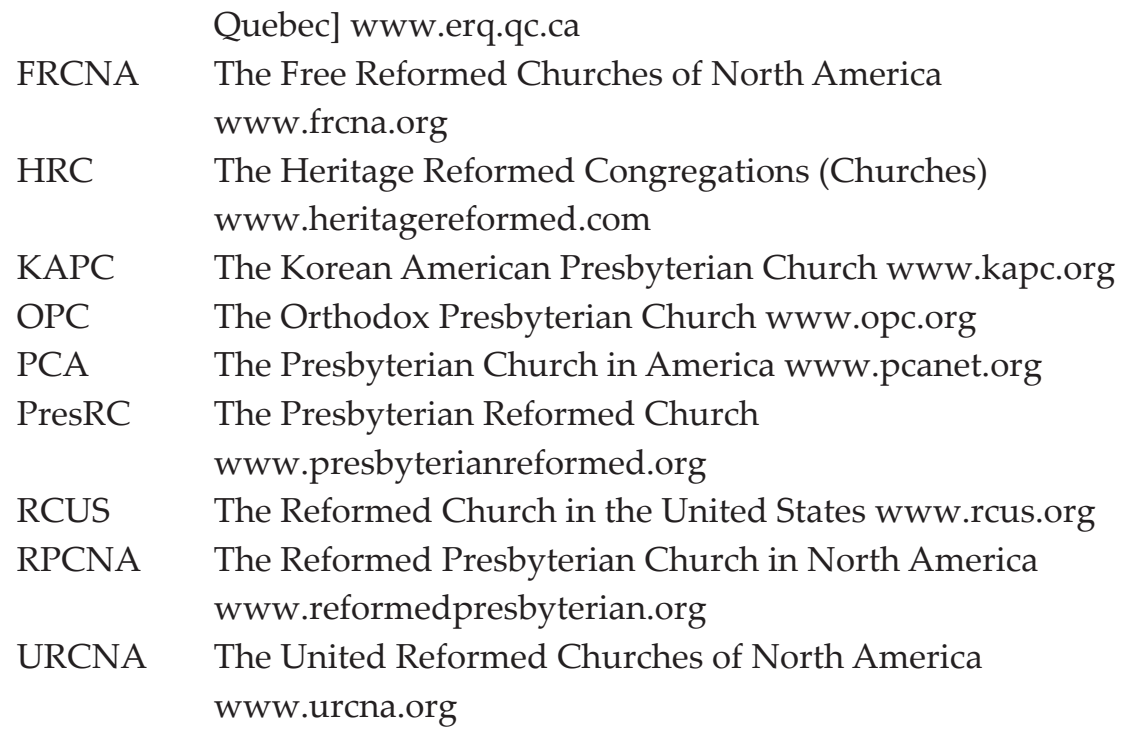

\section{Annotated Bibliography of Collections of Confessions}

Bakhuizen Van Den Brink, Jan Nicolaas, ed. De Nederlandse Belijdenisgeschriften. 1940. 2nd ed. Amsterdam: Bolland, 1976.

Critical edition of the Three Forms of Unity. It includes the Belgic Confession in French (2x), Latin, and Dutch (pp. 60-146); the Heidelberg Catechism in German, Latin, and Dutch (pp. 149-223); the Canons of Dort in Latin and Dutch (pp. 225-87); and the Five Arminian Articles in Dutch and Latin (pp. 288-93).

Beeke, Joel R., and Sinclair B. Ferguson, eds. Reformed Confessions Harmonized with an Annotated Bibliography of Reformed Doctrinal Works. Grand Rapids, Mich.: Baker Books, 1999.

This modern harmony of Reformed confessions contains English translations of the Three Forms of Unity, the Westminster Standards, and the Second Helvetic Confession.

Book of Confessions Study Edition [Part I of the Constitution of the Presbyterian Church (U.S.A.)]. Louisville, Kentucky: Geneva Press, 1996.

Official collection of Confessions of the PCUSA church. It starts with the creeds, continues with 16th century confessions, the Westminster Standards, and ends with 20th century texts (the Declaration of Barmen, the Confession of 1967, and a statement from the PCUSA).

Busch, Eberhard, ed. Reformierte Bekenntnisschriften. Vols. 1:1, 1523-1534; $1: 2,1535-1549 ; 1: 3,1550-1558 ; 2: 1,1559-1563 ; 2: 2,1562-1569 ; 3: 1$, 
1570-1599. Neukirchen-Vluyn: Neukirchener, 2002-2012.

Comprehensive critical and most recent edition of the original texts of Reformed confessions.

Cochrane, Arthur C., ed. Reformed Confessions of the 16th Century. Philadelphia: The Westminster Press, 1966. Revised edition, Louisville, Ky.: Westminster John Knox, 2003.

This collection gathers English version of 12 Reformed confessions of the 16th century. The Appendix adds the Nicene and Apostles' Creeds, the Heidelberg Catechism and the 20th century Barmen Declaration. This standard work also contains historical introductions.

Dennison, James T, Jr., ed. Reformed Confessions of the 16th and 17th Centuries in English Translation. Volume 1, 1523-1552; Volume 2, 1552-1566; Volume 3, 1567-1599; Volume 4, 1600-1693. Grand Rapids, Mich.: Reformation Heritage Books, 2008-2014.

This comprehensive collection provides the English readers with a translation of most Reformed confessions. These four volumes reaching to the end of the 17th century offer 127 confessions from many different countries.

Ecumenical Creeds and Reformed Confessions. Faith Alive Christian Resources. Grand Rapids, Mich.: CRC Publications, 1988. ${ }^{27}$

This is the official book of confessions of the Christian Reformed Church. It includes the Apostles' Creed, the Nicene Creed, the Athanasian Creed, the Three Forms of Unity (the $\mathrm{HC}$, the $\mathrm{BC}$, and the $\mathrm{CD}$ ) in modern translations with biblical passages and brief historical introductions.

Fatio, Olivier, ed. Confessions et Catéchismes de la foi Réformée. Publications de la Faculté de Théologie de l'Université de Genève 11. Geneva: Labor et Fides, 1986.

Good collection of French versions of Reformed confessions of significance to Reformed French speaking world, including the Creeds, the Geneva Catechism, the French Confession of Faith, the Heidelberg Catechism, the Second Helvetic Confession, and the Canons of Dort.

Gerrish, B. A., ed. The Faith of Christendom: A Source Book of Creeds and Confessions. Meridian Books. Cleveland: World Publishing, 1963.

This anthology focuses on a few representative texts. It starts with the Ecumenical Creeds, continues with texts from the four main branches of

27 In this volume we follow another modern translation of the Three Forms of Unity, that of the Canadian \& American Reformed Churches. The hold to the same six Creeds and Confessions; their translation is available online at http://canrc.org/?page=26\#Creeds. 
the Reformation (Lutheran, Reformed, Anglican, and Anabaptist), and ends with the responses of the Roman Catholic and Eastern Orthodox churches.

Hall, Peter, ed. The Harmony of Protestant Confessions: Exhibiting the Faith of the Churches of Christ Reformed after the Pure and Holy Doctrine of the Gospel, Throughout Europe. Translated from the Latin. London: John F. Shaw, 1840. Repr., Edmonton, Canada: Still Waters Revival Books, 1992. This works resurrects for the English world the Reformed Harmony published at the end of the 16th century. Like the original, this Reformed collection includes Lutheran confessions. In addition to the confessions originally present, it adds the Scot Confession and the following texts that were not yet composed: the Thirty-nine Articles, the Irish Articles, the Canons of Dort, and the Westminster Confession.

Krieg, Matthias, ed. Reformierte Bekenntnisse: Ein Werkbuch als Grundlage für eine Vernehmlassung zum reformierten Bekennen in der Schweiz und zugleich als Geschenk für Jean Calvin zum 500. Geburtstag am 10. Juli 2009.. Zurich: Theologischer Verlag Zurich, 2009.

This collection is presented as a contemporary Swiss confessional manual and a birthday gift for John Calvin. This collection has a wide variety of texts from the Bible to a poetic rendering of the Creed including parts of the Westminster Shorter Catechism, but it includes mainly short excerpts. The approach to confessions is more modern. There is also a French version available and a website associated with this project: www.ref-credo.ch.

Leith, John H., ed. Creeds of the Churches: A Reader in Christian Doctrine from the Bible to the Present. 1963. Rev. ed. Richmond, Virginia: John Knox, 1973. Comprehensive collection of excerpts of Creeds from the Bible to The Confession of 1967. This work is composed from a Reformed perspective, it includes confessions from various theological traditions.

Müller, E. F. Karl, ed. Die Bekenntnisschriften der reformierten Kirche. Leipzig: A. Deichert, 1903. Repr., Die Bekenntnisschriften der reformierten Kirche. 2 vols. Theologische Studien-Texte 5/6. Waltrop: Hartmut Spenner, 1999. This comprehensive collection of Reformed confessions includes texts from the beginning of the sixteenth century to the end of the nineteenth century. It is organized geographically and chronologically. After a detailed introduction in German, the texts are given either in Latin or in the original languages.

Niemeyer, H. A., ed. Collectio confessionum in ecclesiis reformatis publicatarum. Leipzig: J. Klinkhardt, 1840. [Google Books]

Very comprehensive set of Reformed confessions from the 16th and 17th 
century in the original languages. The texts contain only limited Scripture references.

Niesel, Wilhelm, ed. Bekenntnisschriften und Kirchenordnungen der nach Gottes Wort reformierten Kirche. 2nd ed. Zollikon-Zürich: Evangelischer Verlag, 1938.

Critical edition of the originals of chief Reformed confessions of the 16th century and a few doctrinal statements from the decade of the 1930. It significantly also includes Reformed church orders from the time of the Reformation.

Noll, Mark, ed. Confessions and Catechisms of the Reformation. Grand Rapids, Mich.: Baker Books, 1991.

Handy collection of short texts of the time of the Reformation representing the various branches of the church-Lutheran, Reformed, Anabaptist, and Catholic.

Pelikan, Jaroslav, and Valerie Hotchkiss, eds. Part Four: Creeds and Confessions of the Reformation Era. Vol. 2 of Creeds \& Confessions of Faith in the Christian Tradition. New Haven, Conn.: Yale University Press, 2003.

This is volume two of a four volumes introduction to and collection of creeds and confessions from the inception of the church to the present. Volume two covers confessions from the 16th and 17th centuries from the Lutheran, Reformed, Radical Reformation and Catholic Reformation. This volume includes many of the confessions in our volume; not, however, Beza's confession and the Westminster Larger Catechism. The texts are presented in English translations and are accompanied by updated introductions and bibliographies. The volume also includes useful indices.

Plasger, Georg, and Matthias Freudenberg, eds. Reformierte Bekenntnisschriften: Eine Auswahl von den Anfängen bis zur Gegenwart. Göttingen: Vandenhoeck \& Ruprecht, 2005.

Collection of Reformed confessions in German. The introduction and choice of confessions follows the footsteps of Karl Barth. For the period of the Reformation, the selection of texts focuses on the continental Reformation and ends of the Canons of Dort and the book includes five modern confessions including the Barmen Declaration.

Schaff, Philip, ed. The Creeds of Christendom with a History and Critical Notes. Revised by David S. Schaff. 3 vols. 6th ed. 1931. Repr., Grand Rapids, Mich.: Baker Books, 1983.

Still one of the most comprehensive and valuable collections of Confessions. 
It spans from the Bible to the mid twentieth century, includes confessions from all major branches of Christianity, and contains original texts as well as English translations.

Torrance, Thomas, F., ed. The School of Faith: The Catechisms of the Reformed Church. New York: Harper \& Brothers, 1959.

As Cochrane gathered the Reformed confessions in English, so this work provides a collection of Reformed catechisms in English translations, especially those significant for Scotland (including the Westminster Catechisms). Torrance provides a long introductions with neo-orthodox leanings.

Westminster Confession of Faith. 1646. Repr., Glasgow: Free Presbyterian Publications, 1958, 1990. This is a reprint of The Confession of Faith; The Larger and Shorter Catechisms, With the Scripture Proofs at Large: Together with the Sum of Saving Knowledge. London: T. Nelson and Sons, Paternoster Row, 1857.

This volume contains the Westminster Standards: the Confession and the two catechisms. It also includes several other important documents associated with the Westminster assembly such "The Solemn League and Covenant (1643-1644)" and "The Directory for the Publick Worship of God" among others. 